\title{
Screening of individuals of age group 25 years and above for hypertension and diabetes in urban slum community, Sion, Mumbai
}

\section{Deepali Mohan Kadam*, Shobha Kowli, Satish Mali}

Department of Community Medicine, K. J. Somaiya Medical College and Research Centre, Sion, Mumbai, Maharashtra, India

Received: 08 April 2016

Accepted: 02 May 2016

\section{*Correspondence:}

Dr. Deepali Mohan Kadam,

E-mail: deepalikadam411@gmail.com

Copyright: () the author(s), publisher and licensee Medip Academy. This is an open-access article distributed under the terms of the Creative Commons Attribution Non-Commercial License, which permits unrestricted non-commercial use, distribution, and reproduction in any medium, provided the original work is properly cited.

\begin{abstract}
Background: The prevalence of hypertension and diabetes is showing an increasing trend. In India, majority of individuals are not aware of presence of these conditions in self, as they do not undergo regular health checkups. Majority are diagnosed when they undergo routine investigations for surgical procedures or medical examination for some other health problem. These conditions can be detected early, by simple screening techniques such as measuring blood pressure and blood sugar level which can be carried out by trained individuals, leading to reduction in the morbidity and mortality. Hence an initiative was taken to identify and train adolescent volunteers from the community to educate and screen the individuals of urban slum area Pratikshanagar, Sion, Mumbai. Objectives of the study were to screen individuals $\geq 25$ years of age for hypertension and diabetes; to find the level of risk factors like alcohol, tobacco consumption, obesity.

Methods: It is a cross - sectional type of study.

Results: Out of 1119 individuals, $113(10.09 \%)$ were aware of their hypertensive status, thus from the rest 1006 individuals screened, $147(14.61 \%)$ were detected with raised blood pressure. Out of these 147, $86(8.54 \%)$ were confirmed as hypertensive. With regards to diabetes, out of 1119 individuals, $82(7.32 \%)$ were aware of their diabetic status. On screening the rest 1037, 23 (2.21\%) were detected with raised blood sugar. Out of these 23, $13(1.25 \%)$ were confirmed as diabetics.

Conclusions: Volunteers from community can be trained for screening individuals in their locality thus ensuring early detection of hypertension and diabetes.
\end{abstract}

Keywords: Hypertension, Diabetes, Screening, Volunteers

\section{INTRODUCTION}

The prevalence of chronic diseases especially hypertension and diabetes is showing an upward trend in most of the countries. The leading risk factors for these diseases globally are raised blood pressure, tobacco use, and obesity and raised blood glucose. ${ }^{1}$ These risk factors are modifiable. Changing lifestyles and behavioural patterns of people are favourable to the onset of these diseases. The impact of chronic diseases on the lives of people is serious when measured in terms of loss of life, disablement, family hardship, and poverty, and economic loss to the country.

Hypertension is the commonest cardiovascular disorder posing a major public health challenge to population in socio-economic and epidemiological transition. It is one of the major risk factors for cardiovascular mortality which accounts for $20-50 \%$ of all deaths. Worldwide raised blood pressure is estimated to cause 7.5 million deaths, about $12.8 \%$ of the total of all annual deaths. It is a major risk factor for coronary heart disease, ischemic as 
well as haemorrhagic stroke. Globally, overall the prevalence of raised blood pressure in adults aged 25 years and over was around $40 \%$ in 2008. According to survey carried out by Indian Council of Medical Research under the state based integrated disease surveillance project phase I in 2007-08, the prevalence of hypertension was varying from 17 to $21 \%$ in all states with marginal rural-urban difference. ${ }^{2}$

There is also a dramatic increase in the prevalence and incidence of type 2 diabetics in countries showing economic transition. During the year 2004, there were estimated 37.7 million cases of diabetes in the country and the estimated mortality was 1.09 lac. $^{3}$

Both these diseases show an iceberg phenomenon. In the initial phase individuals do not have any symptoms as a result of which many cases are not diagnosed. Health awareness and health seeking behaviour pattern of people in India is different from those of western countries. Majority are not aware of presence of these conditions in self, as they do not undergo regular health checkups. Majority of the individuals in India are diagnosed with hypertension and or diabetes when they undergo routine investigations while undergoing surgical procedures or medical examination for some other health problem. To add to this, there is a problem of non-compliance to treatment, a casual approach towards treatment due to ignorance of the complications of the diseases.

Simple screening techniques such as measuring blood pressure and blood sugar level which can be carried out by trained individuals can be used for early detection of these conditions, leading to reduction in the morbidity and mortality. Hence taking note of this, the Department of Community Medicine of K. J. Somaiya Medical College and Research Centre took an initiative to identify and train adolescent volunteers from the community to educate and screen the individuals of urban slum area Pratiksha nagar, Sion which is the field practice area of the department.

The objectives were,

- $\quad$ To screen individuals $\geq 25$ years of age for hypertension and diabetes.

- To find the level of risk factors like alcohol, tobacco consumption, obesity.

\section{METHODS}

This was a cross sectional study conducted in the Urban Slum Area of Pratiksha Nagar. It is located in F north ward of Mumbai.The study was conducted from August 2011 to March 2012. The study participants were individuals residing at Pratiksha Nagar belonging to the age group $\geq 25$ years. Flipcharts were designed and developed in local language to educate people about Hypertension and Diabetes (Figure 1). In order to ensure community participation adolescent volunteers were identified from the community. They were trained to take blood pressure measurement and check random blood sugar levels (Table 1).
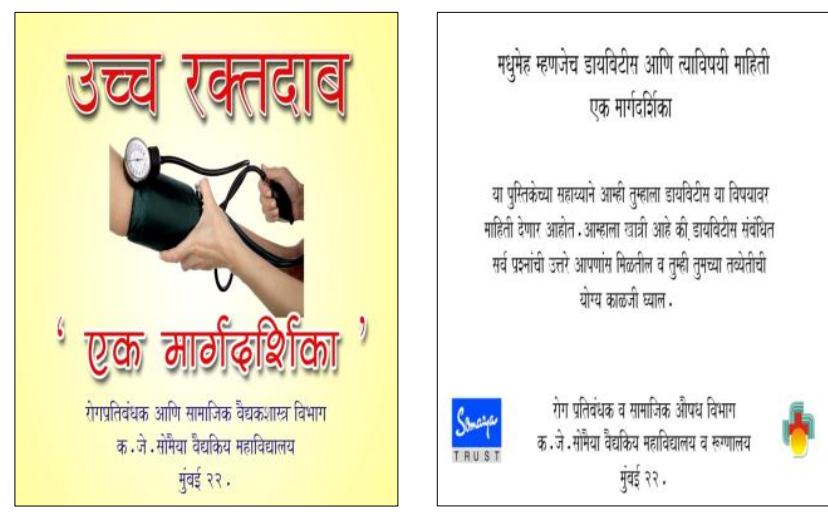

Figure 1: Flipcharts designed on hypertension and diabetes in local language.

Table 1: Schedule for training volunteers from community.

\begin{tabular}{|c|c|c|}
\hline Day & Topics & Duration \\
\hline 1 & $\begin{array}{l}\text { What are chronic diseases? } \\
\text { Importance of screening } \\
\text { Hypertension }\end{array}$ & $\begin{array}{l}45 \text { mins } \\
45 \text { mins }\end{array}$ \\
\hline 2 & $\begin{array}{l}\text { Diabetes } \\
\text { Forms of tobacco, ill effects of } \\
\text { tobacco, and alcohol }\end{array}$ & $\begin{array}{l}45 \text { mins } \\
45 \text { mins }\end{array}$ \\
\hline 3 & $\begin{array}{l}\text { Nutrition, food pyramid, } \\
\text { Importance of high fiber diet } \\
\text { Obesity and its ill effects }\end{array}$ & $\begin{array}{l}45 \text { mins } \\
45 \text { mins }\end{array}$ \\
\hline 4 & $\begin{array}{l}\text { Taking measurements: Height, } \\
\text { Weight, Waist, Hip circumference }\end{array}$ & 2 hours \\
\hline 5 & $\begin{array}{l}\text { Taking blood pressure } \\
\text { Carrying out random blood sugar } \\
\text { investigation }\end{array}$ & $\begin{array}{l}45 \text { mins } \\
45 \text { mins }\end{array}$ \\
\hline 6 & $\begin{array}{l}\text { Filling the questionnaire } \\
\text { Registers to be maintained }\end{array}$ & $\begin{array}{l}1 \& 1 / 2 \mathrm{hrs} \\
1 \& 1 / 2 \mathrm{hrs}\end{array}$ \\
\hline
\end{tabular}

Blood pressure was measured by digital apparatus OMRON HEM 7203 model. Blood sugar levels were measured by dry chemistry glucometer strips CONTOUR Ts Bayer Company.

\section{Inclusion criteria}

Individual $\geq 25$ years of age who gave consent.

\section{Guidelines}

For taking anthropometric, blood pressure and random blood sugar measurements the training and practical guidelines given in STEPS approach by WHO were followed. $^{4}$ 


\section{Definitions}

\section{Raised blood pressure}

An individual who was detected with blood pressure $\geq 140 / 90 \mathrm{mmHg}$. Raised blood sugar: An individual whose random blood sugar level was $\geq 200 \mathrm{mg} / \mathrm{dl}$.

Known case of hypertension, diabetes

An individual diagnosed as hypertensive and or diabetic by a doctor.

\section{Classification}

JNC VII criterion was used to classify blood pressure. ${ }^{5}$ Classification of obesity was done according to body mass index recommended by WHO. ${ }^{6}$

Conduct of the camp (Figure 2).

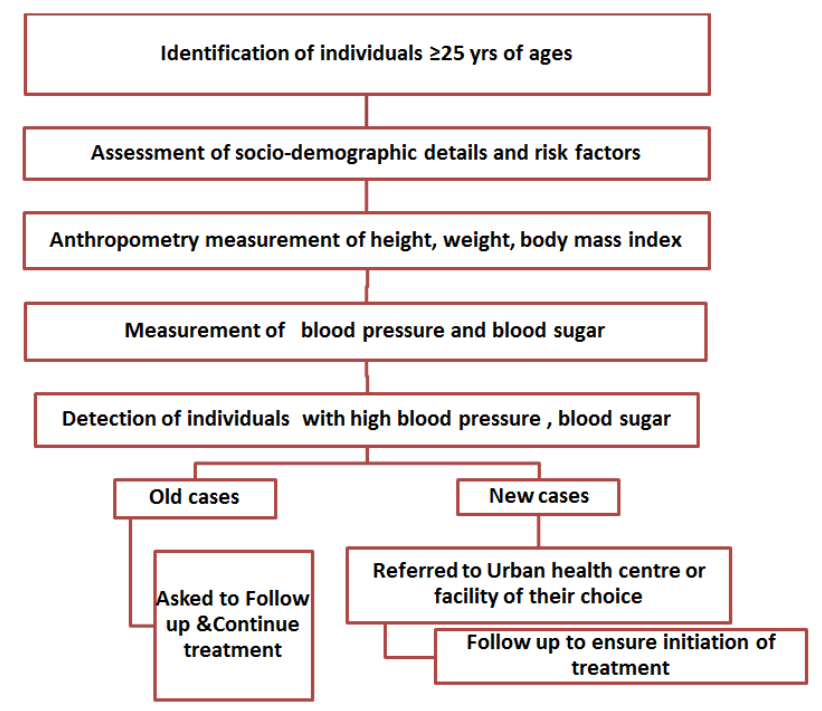

Figure 2: Algorithm of conduct of camp.

Door to door screening was conducted twice in a week by a team comprising of one community health volunteer from the department, two trained adolescent volunteers identified from community. The team used to educate individuals about hypertension and diabetes and motivate them to undergo screening. A written informed consent was taken from the individuals. With the help of semi structured questionnaire, the socio-demographic, risk factor details were obtained followed by measurements of weight, height, hip circumference, waist circumference, blood pressure and blood sugar levels. Blood pressure was taken in the left upper arm. Three readings were taken consecutively with an interval of 2 minutes between two successive readings. Average of the last two readings was noted down. The individuals detected with raised blood pressure were advised to follow up at the Urban Health Centre for three consecutive days to check blood pressure and those with raised blood sugar levels were advised to get a fasting and postprandial blood sugar done.

\section{Data analysis}

The data was entered in Microsoft excel sheet and analysed using "SPSS-16" statistical program. Percentages, chi-square test were calculated.

\section{RESULTS}

Overall 1123 individuals were motivated to undergo blood pressure and blood sugar measurements. 854 $(76.04 \%)$ were females, $265(23.59 \%)$ were males and 4 $(0.35 \%)$ were transgender. Transgender were excluded from analysis $(n=1119)$. Table 2 shows the distribution of study subjects according to age group. The mean age was 40.2years; mean systolic and diastolic blood pressure was 121.9 and $76.2 \mathrm{~mm}$ of $\mathrm{Hg}$ respectively (Table 3 ).

Table 2: Distribution of study subjects according to age.

\begin{tabular}{|lll|}
\hline Age group & Frequency & $(\%)$ \\
\hline $25-34$ & 413 & 36.9 \\
\hline $35-44$ & 320 & 28.6 \\
\hline $45-54$ & 221 & 19.7 \\
\hline $55-64$ & 98 & 8.8 \\
\hline 65 yrs and above & 67 & 6 \\
\hline Total & $* 1119$ & 100.0 \\
\hline
\end{tabular}

$* 4$ transgender excluded from analysis

Table 3: Summary of variables.

\begin{tabular}{|ll|}
\hline Variable & Summary \\
\hline Age (Years) & $40.2+/-12.2(25-90)$ \\
\hline Per capita income/month (Rs) & $1250(111-25000)$ \\
\hline Body mass index & $23.7+/-4.8(12.7-45.8)$ \\
\hline $\begin{array}{l}\text { Systolic blood pressure (mm } \\
\text { of Hg) }\end{array}$ & $121.9+/-18.3(79.5-205.0)$ \\
\hline $\begin{array}{l}\text { Diastolic blood pressure (mm } \\
\text { of Hg) }\end{array}$ & $76.2+/-10.9(46-118.5)$ \\
\hline $\begin{array}{l}\text { Random blood sugar level } \\
\text { (mg/dl) }\end{array}$ & $114.5+/-56.9(51-537)$ \\
\hline
\end{tabular}

Figure 3 shows the no of individuals detected with raised blood pressure and blood sugar on screening and their follow up at the urban health training centre or facility of their choice for confirmatory testing.

Out of 1119 individuals, $113(10.09 \%)$ were already aware of their hypertensive status, thus from the rest 1006 individuals screened, 147 individuals (14.61\%) were detected with raised blood pressure. Out of these 147 individuals, $86(8.54 \%)$ were confirmed as hypertensive (newly diagnosed cases) on follow up at the Urban Health Centre or facility of their choice. Overall; prevalence of Hypertension was $18.63 \%$. 

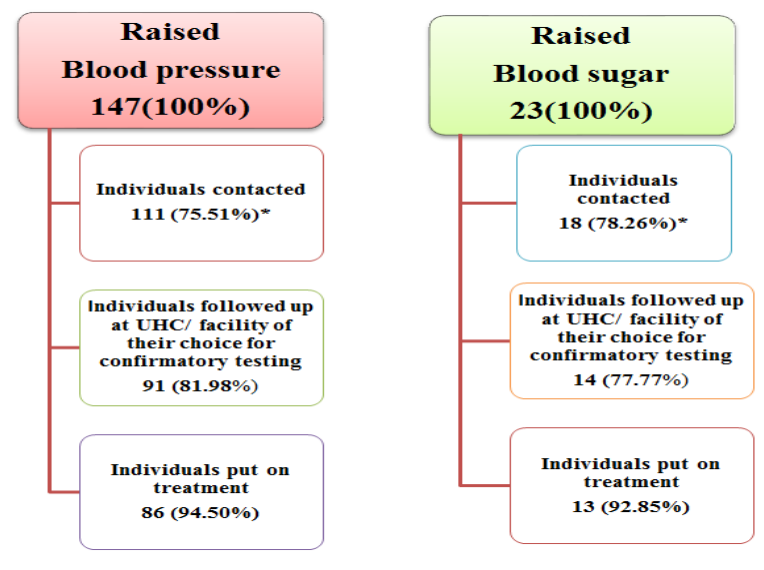

*36 individuals with raised blood pressure and 5 individuals with raised blood sugar could not be contacted

Figure 3: Follow up of individuals detected with raised blood pressure, blood sugar on screening.

With regards to diabetes out of 1119 individuals, $82(7.32 \%)$ individuals were aware of their diabetic status. On screening the rest 1037 individuals, 23 (2.21\%) became aware of raised blood sugar. Out of these 23 subjects, $13(1.25 \%)$ were confirmed as having diabetes. Thus out of 1037 screened, 13 were detected with diabetes. Thus overall prevalence of diabetes was $8.57 \%$.

Figure 4 shows that more males were preobese and obese as compared to females. Consumption of tobacco and alcohol was more among males as compared to females.

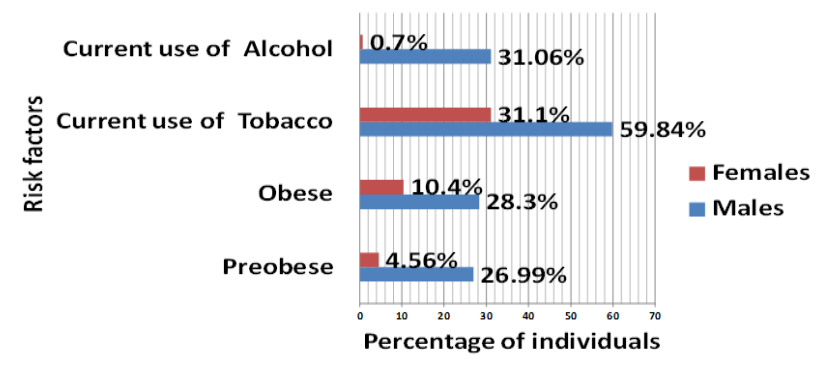

Figure 4: Bar diagram showing the prevalence of risk factors in the community.

Table 4: Distribution of study subjects according to risk factors and category of blood pressure.

\begin{tabular}{|c|c|c|c|c|c|c|c|c|}
\hline \multirow[b]{2}{*}{ Risk factor } & \multicolumn{3}{|l|}{ Males } & \multirow[b]{2}{*}{$\begin{array}{l}\text { Total } \\
\text { n (\%) }\end{array}$} & \multicolumn{3}{|c|}{ Females } & \multirow[b]{2}{*}{$\begin{array}{l}\text { Total } \\
\text { n } \\
(\%)\end{array}$} \\
\hline & $\begin{array}{l}\mathbf{N} \\
\mathrm{n} \\
(\%)\end{array}$ & $\begin{array}{l}\text { Pre HT } \\
\mathrm{n} \\
(\%)\end{array}$ & $\begin{array}{l}\text { HT } \\
\mathrm{n} \\
(\%)\end{array}$ & & $\begin{array}{l}\mathbf{N} \\
\mathrm{n} \\
(\%)\end{array}$ & $\begin{array}{l}\text { Pre HT } \\
\mathrm{n} \\
(\%)\end{array}$ & $\begin{array}{l}\text { HT } \\
\mathrm{n} \\
(\%)\end{array}$ & \\
\hline \multicolumn{9}{|c|}{ Body mass index } \\
\hline Under-weight & $\begin{array}{l}20 \\
(50)\end{array}$ & $\begin{array}{l}12 \\
(30)\end{array}$ & $\begin{array}{l}8 \\
(20)\end{array}$ & $\begin{array}{l}40 \\
(100)\end{array}$ & $\begin{array}{l}91 \\
(78.44)\end{array}$ & $\begin{array}{l}15 \\
(12.93)\end{array}$ & $\begin{array}{l}10 \\
(8.62)\end{array}$ & $\begin{array}{l}116 \\
(100)\end{array}$ \\
\hline Normal & $\begin{array}{l}49 \\
(35)\end{array}$ & $\begin{array}{l}58 \\
(41.42)\end{array}$ & $\begin{array}{l}33 \\
(23.57)\end{array}$ & $\begin{array}{l}140 \\
(100)\end{array}$ & $\begin{array}{l}242 \\
(61.11)\end{array}$ & $\begin{array}{l}107 \\
(27.02)\end{array}$ & $\begin{array}{l}47 \\
(11.86)\end{array}$ & $\begin{array}{l}396 \\
(100)\end{array}$ \\
\hline Preobese & $\begin{array}{l}11 \\
(15.49)\end{array}$ & $\begin{array}{l}33 \\
(46.47)\end{array}$ & $\begin{array}{l}27 \\
(38.02)\end{array}$ & $\begin{array}{l}71 \\
(100)\end{array}$ & $\begin{array}{l}98 \\
(43.17)\end{array}$ & $\begin{array}{l}93 \\
(40.96)\end{array}$ & $\begin{array}{l}36 \\
(15.85)\end{array}$ & $\begin{array}{l}227 \\
(100)\end{array}$ \\
\hline \multirow[t]{3}{*}{ Obese } & $\begin{array}{l}2 \\
(16.66)\end{array}$ & $\begin{array}{l}5 \\
(41.66)\end{array}$ & $\begin{array}{l}5 \\
(41.66)\end{array}$ & $\begin{array}{l}12 \\
(100)\end{array}$ & $\begin{array}{l}24 \\
(27.58)\end{array}$ & $\begin{array}{l}33 \\
(3.44)\end{array}$ & $\begin{array}{l}30 \\
(34.48)\end{array}$ & $\begin{array}{l}87 \\
(100)\end{array}$ \\
\hline & \multicolumn{4}{|c|}{ Chi-square value: $15.483 \mathrm{df}: 6$ p:0.016 } & \multicolumn{4}{|c|}{ Chi-square value: 83.304 df:6 p: 0.00} \\
\hline & $\mathrm{S}$ & & & & $\mathrm{S}$ & & & \\
\hline \multicolumn{9}{|l|}{ Tobacco use } \\
\hline No & $\begin{array}{l}29 \\
(27.35)\end{array}$ & $\begin{array}{l}52 \\
(49.05)\end{array}$ & $\begin{array}{l}25 \\
(23.58)\end{array}$ & $\begin{array}{l}106 \\
(100)\end{array}$ & $\begin{array}{l}344 \\
(58.60)\end{array}$ & $\begin{array}{l}159 \\
(27.08)\end{array}$ & $\begin{array}{l}84 \\
(14.3)\end{array}$ & $\begin{array}{l}587 \\
(100)\end{array}$ \\
\hline \multirow[t]{3}{*}{ Yes } & $\begin{array}{l}54 \\
(34.17)\end{array}$ & $\begin{array}{l}56 \\
(35.44)\end{array}$ & $\begin{array}{l}48 \\
(30.37)\end{array}$ & $\begin{array}{l}158 \\
(100)\end{array}$ & $\begin{array}{l}123 \\
(46.41)\end{array}$ & $\begin{array}{l}91 \\
(34.33)\end{array}$ & $\begin{array}{l}51 \\
(19.24)\end{array}$ & $\begin{array}{l}265 \\
(100)\end{array}$ \\
\hline & \multicolumn{4}{|c|}{ Chi-square value:4.871 df: 2 p: 0.087} & \multicolumn{4}{|c|}{ Chi-square value:11.028 df:2 p:0.004 } \\
\hline & NS & & & & $\mathrm{S}$ & & & \\
\hline \multicolumn{9}{|l|}{ Alcohol use } \\
\hline No & $\begin{array}{l}53 \\
(29.12)\end{array}$ & $\begin{array}{l}85 \\
(46.70)\end{array}$ & $\begin{array}{l}44 \\
(24.17)\end{array}$ & $\begin{array}{l}182 \\
(100)\end{array}$ & $\begin{array}{l}459 \\
(54.25)\end{array}$ & $\begin{array}{l}252 \\
(29.78)\end{array}$ & $\begin{array}{l}135 \\
(15.95)\end{array}$ & $\begin{array}{l}846 \\
(100)\end{array}$ \\
\hline \multirow[t]{3}{*}{ Yes } & $\begin{array}{l}29 \\
(35.36)\end{array}$ & $\begin{array}{l}24 \\
(29.26)\end{array}$ & $\begin{array}{l}29 \\
(35.36)\end{array}$ & $\begin{array}{l}82 \\
(100)\end{array}$ & $\begin{array}{l}3 \\
(50)\end{array}$ & $\begin{array}{l}2 \\
(33.33)\end{array}$ & $\begin{array}{l}1 \\
(16.6)\end{array}$ & $\begin{array}{l}6 \\
(100)\end{array}$ \\
\hline & \multicolumn{4}{|c|}{ Chi-square value:7.432 df: 2 p: 0.024} & \multicolumn{4}{|c|}{ Chi-square value: $0.286 \mathrm{df:} 2 \mathrm{p}: 0.866$} \\
\hline & $\mathrm{S}$ & & & & NS & & & \\
\hline
\end{tabular}

N= Normal PreHT= Pre Hypertension HT= Hypertension S= Significant NS = Not significant 
In both males and females who were preobese and obese more no of subjects were found to have prehypertension and hypertension as well as raised blood sugar as compared to those who had normal body mass index (Table 4, 5). Association between tobacco use and hypertension was not found to be significant in males whereas it was significant in females (Table 4).
Association between alcohol use and hypertension was found to be significant in males whereas it was not significant in females (Table 3). No significant association was found between tobacco, alcohol use and hypertension and raised blood sugar in males and females in this study (Table 4, 5).

Table 5: Distribution of study subjects according to risk factors and category of blood sugar.

\begin{tabular}{|c|c|c|c|c|c|c|c|}
\hline \multirow[b]{2}{*}{ Risk factor } & \multicolumn{2}{|l|}{ Males } & \multirow[b]{2}{*}{$\begin{array}{l}\text { Total } \\
\text { n } \\
(\%)\end{array}$} & \multicolumn{2}{|l|}{ Females } & \multirow[b]{2}{*}{$\begin{array}{l}\text { Total } \\
\text { n } \\
(\%)\end{array}$} & \\
\hline & $\begin{array}{l}\text { Normal } \\
\mathbf{n} \\
(\%)\end{array}$ & $\begin{array}{l}\text { Raised } \\
\text { n } \\
(\%)\end{array}$ & & $\begin{array}{l}\text { Normal } \\
\mathbf{n} \\
(\%)\end{array}$ & $\begin{array}{l}\text { Raised } \\
\text { n } \\
(\%)\end{array}$ & & \\
\hline \multicolumn{8}{|c|}{ Body mass index } \\
\hline *Underweight & $\begin{array}{l}39 \\
(97.5)\end{array}$ & $\begin{array}{l}1 \\
(2.5)\end{array}$ & $\begin{array}{l}40 \\
(100)\end{array}$ & $\begin{array}{l}115 \\
(99.13)\end{array}$ & \multicolumn{2}{|l|}{$\begin{array}{l}1 \\
(0.86)\end{array}$} & $\begin{array}{l}116 \\
(100)\end{array}$ \\
\hline *Normal & $\begin{array}{l}129 \\
(92.14)\end{array}$ & $\begin{array}{l}11 \\
(7.85)\end{array}$ & $\begin{array}{l}140 \\
(100)\end{array}$ & $\begin{array}{l}378 \\
(95.93)\end{array}$ & \multicolumn{2}{|l|}{$\begin{array}{l}16 \\
(4.06)\end{array}$} & $\begin{array}{l}394 \\
(100)\end{array}$ \\
\hline Preobese & $\begin{array}{l}64 \\
(91.42)\end{array}$ & $\begin{array}{l}6 \\
(8.57)\end{array}$ & $\begin{array}{l}70 \\
(100)\end{array}$ & $\begin{array}{l}220 \\
(93.61)\end{array}$ & \multicolumn{2}{|l|}{$\begin{array}{l}15 \\
(6.38)\end{array}$} & $\begin{array}{l}235 \\
(100)\end{array}$ \\
\hline \multirow[t]{3}{*}{ Obese } & $\begin{array}{l}9 \\
(69.23)\end{array}$ & $\begin{array}{c}4 \\
(30.76)\end{array}$ & $\begin{array}{l}13 \\
(100)\end{array}$ & $\begin{array}{l}72 \\
(87.80)\end{array}$ & \multicolumn{2}{|l|}{$\begin{array}{l}10 \\
(12.19)\end{array}$} & $\begin{array}{l}82 \\
(100)\end{array}$ \\
\hline & \multicolumn{3}{|c|}{$\begin{array}{l}\text { Chi-square value: } 6.338 \mathrm{df}: 2 \mathrm{p}: 0.04 * \\
\text { Values clubbed }\end{array}$} & \multicolumn{4}{|c|}{ Chi-square value:11.889 df:3p:0.007 } \\
\hline & $\mathrm{S}$ & & & $\mathrm{S}$ & & & \\
\hline \multicolumn{8}{|l|}{ Tobacco use } \\
\hline No & $\begin{array}{l}98 \\
(92.45)\end{array}$ & $\begin{array}{l}8 \\
(7.54)\end{array}$ & $\begin{array}{l}106 \\
(100)\end{array}$ & $\begin{array}{l}554 \\
(95.02)\end{array}$ & $\begin{array}{l}29 \\
(4.97)\end{array}$ & \multicolumn{2}{|l|}{$\begin{array}{l}583 \\
(100)\end{array}$} \\
\hline \multirow[t]{3}{*}{ Yes } & $\begin{array}{l}144 \\
(91.13)\end{array}$ & $\begin{array}{l}14 \\
(8.86)\end{array}$ & $\begin{array}{l}158 \\
(100 \%)\end{array}$ & $\begin{array}{l}250 \\
(94.33)\end{array}$ & $\begin{array}{l}15 \\
(5.66)\end{array}$ & $\begin{array}{l}265 \\
(100)\end{array}$ & \\
\hline & \multicolumn{3}{|c|}{ Chi-square value:0.143 df:1 p:0.70 } & \multicolumn{4}{|c|}{ Chi-square value: $0.174 \mathrm{df}: 1 \mathrm{p}: 0.67$} \\
\hline & \multicolumn{3}{|c|}{ NS } & \multicolumn{4}{|c|}{ NS } \\
\hline \multicolumn{8}{|l|}{ Alcohol use } \\
\hline No & $\begin{array}{l}166 \\
(91.2)\end{array}$ & $\begin{array}{l}16 \\
(8.79)\end{array}$ & $\begin{array}{l}182 \\
(100)\end{array}$ & $\begin{array}{l}798 \\
(94.77)\end{array}$ & $\begin{array}{l}44 \\
(5.22)\end{array}$ & \multicolumn{2}{|l|}{$\begin{array}{l}842 \\
(100 \%)\end{array}$} \\
\hline \multirow[t]{2}{*}{ Yes } & $\begin{array}{l}76 \\
(92.68)\end{array}$ & $\begin{array}{l}6 \\
(7.31)\end{array}$ & $\begin{array}{l}82 \\
(100)\end{array}$ & $\begin{array}{l}6 \\
(100)\end{array}$ & $\begin{array}{l}0 \\
(0)\end{array}$ & $\begin{array}{l}6 \\
(100)\end{array}$ & \\
\hline & \multicolumn{3}{|c|}{ Chi-square value: $0.161 \mathrm{df}: 1 \mathrm{p}: 0.68$} & \multicolumn{4}{|c|}{ Chi-square value: $0.121 \mathrm{df:} 1 \mathrm{p}: 0.72$} \\
\hline
\end{tabular}

\section{DISCUSSION}

Out of 147 individuals with raised blood pressure, 111 could be contacted by the volunteers. From Figure 2 it is seen that out of $111,91(81.98 \%)$ individuals went for confirmatory testing at the urban health centre or facility of their choice and out of these $86(94.50 \%)$ were put on treatment. Out of 23 individuals with raised blood sugar, 18 could be contacted by the volunteers. From Figure 2 it is seen that out 18 , with raised blood sugar $14(77.77 \%)$ individuals went for confirmatory testing. 13 individuals $(92.85 \%)$ were started on treatment
The follow up rates were good as compared to a home based screening study conducted in western Kenya where $31 \%$ and $22 \%$ of individuals returned for confirmatory testing for blood pressure and blood sugar respectively. ${ }^{7}$

Various epidemiological studies conducted in India, report an increasing prevalence of hypertension and diabetes. Several studies report a higher prevalence of hypertension in urban areas $20-40 \%$. The number of people with diabetes is expected to rise by $195 \%$ in India during 1995-2025 to reach 57.2 million in $2025 .{ }^{8}$ The overall prevalence of hypertension and diabetes in this study was $18.63 \%$ and $8.57 \%$ respectively. The 
prevalence of hypertension is more as compared to $7.24 \%$ in a study conducted by Sampatti Todkar et al in 2009 in Maharashtra. ${ }^{9}$ Another study conducted by Joshi S V et al 2000, in Mumbai, reported prevalence of $7.82 \%{ }^{10}$ The prevalence found in this study is less as compared to $44 \%$ and $21 \%$ reported by Gupta et al in Mumbai ${ }^{11}$ and Mohan et $\mathrm{al}^{12}$ in Jaipur. Pooled epidemiological studies show the average prevalence of hypertension in India as $25 \% .^{13}$

The national Urban Diabetes Survey by V. Mohan et al. conducted in six metropolitan cities across India reported an overall prevalence of $12.1 \%$ of type 2 diabetes and that for Mumbai as $9.3 \% .^{14}$ The prevalence in this study was $8.57 \%$ almost similar to that reported in the National Urban Diabetes Survey conducted by Ramachandran A et al. ${ }^{15}$ The prevalence is less as compared to $15.5 \%$ reported by CURES study in Chennai. ${ }^{14}$

Out of 1119 subjects $360(32.2 \%)$ were detected with Prehypertension, 146 (13\%), 62 (5.5\%) were detected with stage I and stage II hypertension respectively. These results are similar to CURES-52 study conducted in Chennai by $\mathrm{V}$ Mohan et al where the percentages of Prehypertensive, Stage 1 and stage 2 hypertension were $36.15,15.1 \%$ and $4.9 \%$ respectively. ${ }^{16}$ These differ from the study conducted by Shyamal Kumar Das et al where the percentages were $58.7,32.5$ and 21.8 respectively. ${ }^{17}$

$113(10.09 \%)$ were already aware of their hypertensive status in our study as compared to $6.6 \%$ reported in CURES-52 study. ${ }^{16}$ The $\%$ is less as compared to $33.8 \%$ who were aware of their hypertensive status in study conducted by B.Y.Yuvraj et al in Davanagere. ${ }^{18}$ The percentage of self-reported Hypertensive status was $16.6 \%$ in study done by Sanjay Kinra et al. ${ }^{19}$

$82(7.32 \%)$ were already aware of their diabetic status. The prevalence of known diabetes was similar to that found in CURES study. ${ }^{13} 1.25 \%$ were confirmed as having diabetes. This percentage is less as compared to the $9.1 \%$ of undiagnosed diabetics reported in the CURES study. ${ }^{20}$ Similarly, it is less as compared to the $10.5 \%$ of undiagnosed diabetics found in the ADEPS study. $^{21}$

$59.84 \%$ and $31.06 \%$ of men reported current use of tobacco and alcohol in this study. Similar results were seen in study carried out in Haryana by Krishnan et al where tobacco consumption was $48.1 \%$ in men and alcohol consumption was $24.6 \% .^{22}$ Higher prevalence of tobacco consumption $31.1 \%$ was reported in women. This $\%$ is more as compared to $4.4 \%$ found in a study conducted in rural areas of India conducted by Sanjay Kinra et al. ${ }^{19} 0.7 \%$ of women reported use of alcohol. A nationwide survey in 1993-1994 revealed that $23.2 \%$ of males and $4 \%$ of females consumed tobacco in any form in urban areas. ${ }^{23}$

Prevalence of obesity was more in men as compared to women. In males and females hypertension was significantly associated with greater BMI. Similar finding was reported in a study conducted by Sushil K Bansal et al in north-east India. ${ }^{24}$ Study by Singh R.B. et al in five cities of India also showed a strong association of Hypertension and BMI in women. ${ }^{25}$ In females hypertension was significantly associated with tobacco use. In males hypertension was significantly associated with alcohol use.

In males as well as females, raised blood sugar was significantly associated with increase in BMI but it was not associated with tobacco and alcohol use.

The uniqueness of the study was the involvement of adolescent volunteers from the community in conducting the screening and follow-up of the individuals. There are several other studies conducted in Kenya, America where community health volunteers were trained to carry out screening. $7,26,27$

This study model can be easily replicated in urban as well as rural areas. It would ensure community participation and lead to capacity building of the community.

\section{ACKNOWLEDGEMENTS}

We are grateful to Pallai Developers for the financial support. We thank the adolescent volunteers from the community for their participation in screening the individuals. We acknowledge the support of the staff members of the department. We thank the study subjects for their co-operation.

Funding: Funding was provided by Pallai developers, Mumbai

Conflict of interest: None declared

Ethical approval: The study was approved by the Institutional Ethics Committee

\section{REFERENCES}

1. WHO: Chronic Diseases: causes and health impacts. In: Preventing chronic diseases: A Vital Investment: WHO Global Report. Geneva: World Health Organisation; 2005:34-58.

2. Park K. Hypertension. In: Park's textbook of Preventive and Social Medicine. $22^{\text {nd }}$ edition: M/s Banardasidas Bhanot publishers; 2013:344-348.

3. Park K. Obesity. In: Park's textbook of Preventive and Social Medicine. 22 $2^{\text {nd }}$ edition: M/s Banarsidas Bhanot publishers; 2013:362-367.

4. WHO. Part 3: Training and practical guides. In: STEPS manual. WHO; 2008:3-3-2-3-3-13.

5. The seventh report of Joint National Committee on prevention, detection, evaluation and treatment of high blood pressure NIH publication no.03-5233 December 2003 U.S. department of health and human services. National Institute of Health. National Heart, Lung, Blood Institute, national high Blood Pressure Education Program. JNC 7 Express. 
6. Park K. Obesity. In: Park's textbook of Preventive and Social Medicine. $22^{\text {nd }}$ edition. M/s Banardasidas Bhanot publishers; 2013:367-371.

7. Pastakia S, Ali S, Kamano J, Akwanalo C, Ndege S, Buckwalter V, Vedanthan R, Bloomfield G. Screening for diabetes and hypertension in a rural low income setting in western Kenya utilizing home-based and community based strategies. Global health. 2013;9:21.

8. Abdul G, Reddy K, Singhi M. Burden of noncommunicable diseases in South Asia. BMJ. 2004;328:807.

9. Todkar S, Gujarathi V, Tapare S. Period prevalence and sociodemographic factors of hypertension in rural Maharashtra: a cross-sectional study. Indian J Comm Med. 2009;34(3):183-7.

10. Joshi V, Patel C, Dhar L. Prevalence of Hypertension in Mumbai. Indian $\mathrm{J}$ Med Sci. 2000;54:380-3.

11. Gupta PC, Gupta R, Pednekar M. Hypertension prevalence and blood pressure trends in 88653 subjects in Mumbai, India. J Hum Hypertens. 2004; 18:853-6.

12. Mohan V, Gukulkrishnan K, Unnikrishnan R, Deepa R. Epidemiology of hypertension in India: lessons from the chennai urban population study. In type 2 diabetes in South Asians: epidemiology. Risk Factors and Prevention (cds Mohan, V. and Rao,G. H. R.), Jaypee Brothers, New Delhi; 2007:317-330.

13. Gupta R. Rethinking diseases of affluence; coronary heart disease in developing countries. South Asian J Preven Cardiol. 2006;10(2):65-78.

14. Mohan V, Sandeep S, Deepa R, Shah B, Varghese C. Epidemiology of type 2 diabetes: Indian scenario. Indian J Med Res. 2007;125:217-30.

15. Ramachandran A, Snehalatha C, Kapur A, Vijay V, MohanV, Das AK, et al. Diabetes Epidemiology Study Group in India (DESI). High prevalence of diabetes and impaired glucose tolerance in India. National Urban Diabetes Survey. Diabetologia. 2001;44:1094-101.

16. Mohan V, Deepa M, Farooq S, Datta M, Deepa R. Prevalence, Awareness and control of Hypertension in Chennai-The Chennai Urban Rural Epidemiology Study (Cures- 52). JAPI. 2007;55:326-32.

17. Das K, Sanyal K, Basu A. Study of urban community survey in India: growing trend of high prevalence of hypertension in a developing country. Int J Med Sci. 2005;2(2):70-8.

18. Yuvaraj BY, Nagendra Gowda MR, Umakantha AG. Prevalence, awareness, treatment, and control of hypertension in rural areas of Davanagere. Indian J Comm Med. 2010;35:138-41.
19. Kinra S, Bowen L, Lyngdoh T, Prabhakaran D, Srinath Reddy K, Ramakrishnan L et al. Sociodemographic patterning of non-communicable disease risk factors in rural India: a cross sectional study. BMJ. 2010;341.

20. Mohan V, Deepa M, Deepa R, Shantirani CS, Farooq S, Ganesan A, et al. Secular trends in the prevalence of diabetes and glucose tolerance in urban South India-the Chennai Urban Rural Epidemiology Study (CURES-17). Diabetologia. 2006;49:1175-8.

21. Menon VU, Kumar KV, Gilchrist A, Sugathan TN, Sundaram KR, Nair V, et al. Prevalence of known and undetected diabetes and associated risk factors in central Kerala-ADEPS. Diabetes Res Clin Pract. 2006;74:289-94.

22. Krishnan A, Shah B, Lal V, Shukla DK, Paul E, Kapoor SK. Prevalence of risk factors for noncommunicable disease in a Rural Area of Faridabad District of Haryana. Indian $\mathbf{J}$ Pub Health. 2008;52(3):117-24.

23. Committee on NSSO. Sarvekshana, Journal of the National Sample Survey Organization, Department of Statistics, Ministry of Planning, Government of India, January-March 1998;76.

24. Bansal K, Saxena V, Kandpal S, Gray W, Walker R, Goel D. The prevalence of hypertension and hypertension risk factors in a rural Indian community: a prospective door-to-door study. J Cardiovasc Dis Res. 2012;3(2):117-23.

25. Singh RB, Pella D, Mechirova V, Kartikey K, Demeester F, Tomar RS et al. Prevalence of obesity, physical inactivity and under nutrition, a triple burden of diseases during transition in a developing economy. The five city study group. Acta Cardiol. 2007;62(2):119-27.

26. Brownstein N, Bone L, Dennison C, Hill M, Kim M, Levine D. Community Health Workers as Interventionists in the Prevention and Control of Heart Disease and Stroke. Am J Prev Med. 2005;29(5S1):128-33.

27. Elder JP, McKenna CA, Lazieh M, Ferreira A, Lasater TM, Carleton RA. The use of volunteers in mass screening for high blood pressure. Am J Prev Med. 1986;2(5):268-72.

Cite this article as: Kadam DM, Kowli S, Mali S. Screening of individuals of age group 25 years and above for hypertension and diabetes in urban slum community, Sion, Mumbai. Int J Community Med Public Health 2016;3:1303-9. 